\title{
Identification of histamine receptor subtypes in skeletal myogenesis
}

\author{
${\text { YAN } \text { CHEN }^{1-3} \text {, VASILY STEGAEV }}^{1,2}$, VESA-PETTERI KOURI ${ }^{1,2}$, TARVO SILLAT $^{1,2}$, PAUL L. CHAZOT ${ }^{4}$, \\ HOLGER STARK $^{5}$, JIAN GUO WEN ${ }^{3}$ and YRJÖ T. KONTTINEN ${ }^{1,6,7}$

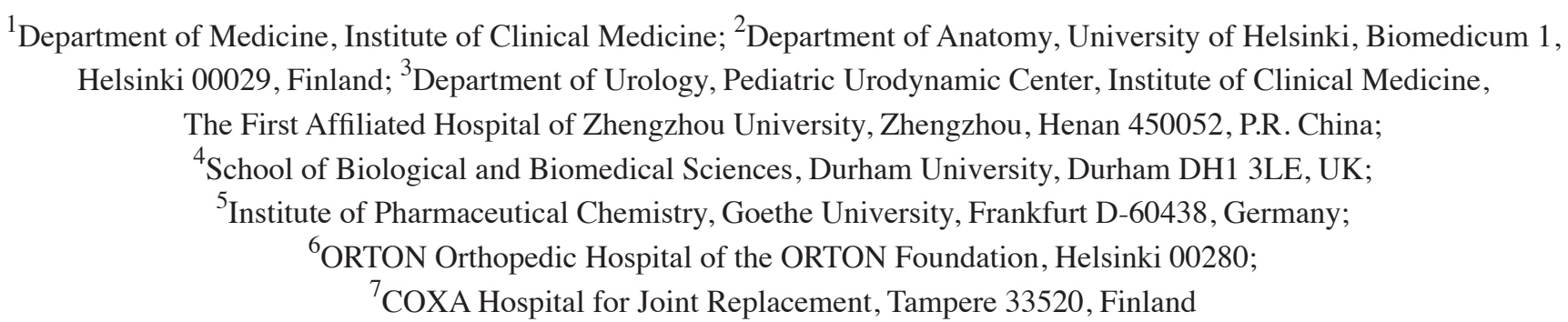

Received June 4, 2014; Accepted November 20, 2014

DOI: $10.3892 / \mathrm{mmr} .2014 .3073$

\begin{abstract}
To date, conventional and/or novel histamine receptors (HRs) have not been investigated in mouse skeletal myogenesis. Therefore, the present study aimed to investigate the HR-subtypes in skeletal myogenesis. The myogenesis of $\mathrm{C} 2 \mathrm{C} 12$ skeletal myoblasts was evaluated using desmin, myogenin and myosin heavy chain (Myh) as early, intermediate and late differentiation markers, respectively. Reverse transcription-quantitative polymerase chain reaction and immunostaining were performed and the messenger RNA (mRNA) expression levels of the HR-subtypes and markers were determined. $\mathrm{H}_{1} \mathrm{R}$ mRNA was found to be highly expressed in myoblasts at day 0; however, the expression levels were reduced as differentiation progressed. By contrast, $\mathrm{H}_{2} \mathrm{R}$ mRNA expression remained constant, while $\mathrm{H}_{3} \mathrm{R}$ mRNA expression increased by 28-, 103- and 198-fold at days 2, 4 and 6 compared with the baseline level (day 0), respectively. In addition, Myh expression increased by 7,718-, 94,487- and 286,288-fold on days 2, 4 and 6 compared with the baseline expression level (day 0 ). Weak positive staining of the cells for $\mathrm{H}_{3} \mathrm{R}$ protein was observed on day 2 , whereas highly positive staining was observed on days 4 and 6 . HR expression during myogenesis was, in part, regulated by the stage of differentiation. These results along with previous findings indicated possible involvement of $\mathrm{H}_{1} \mathrm{R}$ in the regulation of progenitor cell mitogenesis and
\end{abstract}

Correspondence to: Professor Yrjö T. Konttinen, Department of Medicine, Institute of Clinical Medicine, University of Helsinki, Biomedicum 1, PO Box 700 (Haartmaninkatu 8), Helsinki 00029, Finland

E-mail: yrjo.konttinen@helsinki.fi

Key words: myogenesis, differentiation, histamine receptor type 3, histamine of $\mathrm{H}_{2} \mathrm{R}$ in the relaxation of acetylcholine-stimulated contraction of muscle cells, following the activation of professional histamine-producing cells, including mast cells. By contrast, $\mathrm{H}_{3} \mathrm{R}$ may participate in the regulation of specialized myocyte functions, potentially by maintaining the relaxed state under the influence of constitutive $\mathrm{H}_{3} \mathrm{R}$ activity and low histamine concentrations, locally produced/released by non-professional histamine-producing cells.

\section{Introduction}

Histamine is a well-known biogenic and cationic amine, which is synthesized, stored and released by professional histamine-synthesizing cells. Mast cells, basophils and enterochromaffin cells contain the endoplasmic $54 \mathrm{kDa}$ histidine decarboxylase (HDC), which converts L-histidine to histamine (1). Histamine is released into and stored within storage granules, prior to regulated release (1). Following activation of professional histamine-producing cells, a burst release results in a transient high histamine concentration in the extracellular space. These transient histamine concentrations are sufficient to stimulate the conventional histamine receptors, histamine receptor type $1\left[\mathrm{H}_{1} \mathrm{R}\right.$; binding affinity $\left.\left(\mathrm{pK}_{\mathrm{i}}\right)=4.2\right]$ and histamine receptor type $2\left(\mathrm{H}_{2} \mathrm{R} ; \mathrm{pK}_{\mathrm{i}}=4.3\right)(2)$. Smooth muscle cells $(3,4)$, cardiomyocytes $(5,6)$ and skeletal muscle tissue $(7)$ express these conventional histamine receptors, which regulate cellular proliferation and the contraction state of the cells stimulated via the histamine $/ \mathrm{H}_{1} \mathrm{R}$ or $\mathrm{H}_{2} \mathrm{R}$ axes (3-6).

A previous study identified that the cytoplasmic $73 \mathrm{kDa}$ 'pro-form' of HDC produced histamine, however, at a 100-1,000-fold lower rate compared with the typical enzyme isoform of the professional histamine-synthesizing cells (1). In non-professional histamine-producing cells, histamine is released into the cellular cytoplasm rather than being stored, and is therefore not subjected to regulated burst release (8). These cells contain organic cation transporters, which are equilibrative uniporters and transport the intracellularly synthesized 
Table I. Primer sequences used in reverse transcription-quantitative polymerase chain reaction and the corresponding amplicon lengths.

\begin{tabular}{llccc}
\hline Gene & Forward primer & Reverse primer & Length (bp) \\
\hline Des & 5'-GCCCTCAAGGGCACCAACGA-3' & 5'-TTGCTCGGGGCTGGTTTCTCG-3' & 297 \\
Myog & 5'-CCCAACCAGCGGCTGCCTAA-3' & 5'-GTAGGGTCAGCCGCGAGCAA-3' & 245 \\
Myh2 & 5'-AGCTGCACCTTCTCGTTTGCCA-3' & 5'-CGGTCAGGGTCGCTCCTGCT-3' & 261 \\
$\mathrm{H}_{1} \mathrm{R}$ & 5'-CACTGGAGGCTGCCCTTGTGC-3' & 5'-CACCAGCAGGTTGAGGCCCAC-3' & 167 \\
$\mathrm{H}_{2} \mathrm{R}$ & 5'-TCCTAAGCGACCCGGTACAGC-3' & 5'-ATGGAGACTGAGGCACTGCTGG-3' & 208 \\
$\mathrm{H}_{3} \mathrm{R}$ & 5'-TTCGAGCCTCCGCACCCAGAA-3' & 5'-GGTCCAACGGCCGGTCAGC-3' & 118 \\
$\mathrm{H}_{4} \mathrm{R}$ & 5'-TGCTCAGGTCCCCTTGGCATTT-3' & 5'-ACGTGAGGGATGTACAGAGGAATGG-3' & 189 \\
PBGD & 5'-AAAGTGCCGTGGGAACCAGC-3' & 5'-CAGCCACAGCCAGGACGATG-3' & 156 \\
\hline
\end{tabular}

Des, desmin; Myog, myogenin; Myh2, myosin heavy chain IIa; $\mathrm{H}_{\mathrm{n}} \mathrm{R}$, histamine receptor type $\mathrm{n}(\mathrm{n}=1-4)$; PBGD, porphobilinogen deaminase.

histamine from the non-professional histamine synthesizing cells along the histamine concentration gradient to the extracellular space (8). Histamine concentrations achieved in this manner are not sufficient to stimulate conventional histamine receptors. Therefore, this mechanism was hypothesized to represent an ancestral vestigium of a function that had become obsolete during phylogenesis. However, studies conducted within the last decade that focus on G-protein coupled receptors have revealed novel members of the histamine receptor family (2). These novel histamine receptors, histamine receptor type $3\left(\mathrm{H}_{3} \mathrm{R}\right.$; $\left.\mathrm{pK}_{\mathrm{i}}=8.0\right)$ and histamine receptor type $4\left(\mathrm{H}_{4} \mathrm{R} ; \mathrm{pK}_{\mathrm{i}}=8.2\right)$, have $>10,000$-fold greater affinity for histamine compared with the conventional receptors (2). In addition, the low basal levels of histamine produced by non-professional histamine-producing cells, including dendritic cells (9) and lymphocytes $(10,11)$, have been demonstrated to be sufficient in order to bind to and regulate cells equipped with these novel, high-affinity histamine receptors. The role of high histamine concentration in the regulation of muscle cell tone was investigated in previous studies (3-6). Studies using histamine receptor agonists and/or antagonists have suggested that novel histamine receptors may also be present and functional in the bronchial smooth muscle cells at least (3). However, to date, no studies indicating the presence of histamine receptors at the messenger RNA (mRNA) and protein level in myoblasts, myocytes or myotubes during skeletal myogenesis have been reported. Due to the presence and role of $\mathrm{H}_{1} \mathrm{R}, \mathrm{H}_{2} \mathrm{R}$ and $\mathrm{H}_{3} \mathrm{R}$ in the function of other muscle cell types, the present study aimed to assess whether striated muscle cells synthesize and express the histamine receptors, $\mathrm{H}_{3} \mathrm{R}$ and $\mathrm{H}_{4} \mathrm{R}$. In addition, the current study investigated whether these receptors are developmentally regulated during myogenesis in association with various markers of myogenic maturation.

\section{Materials and methods}

Cell culture. The present study was approved by the institutional Medical Ethics Committee of the Institue of Clinical Medicine, University of Helsinki (Helsinki, Finland) and was performed in accordance with the 1983 Declaration of Helsinki. Mouse C2C12 myoblasts were obtained from the Turku Center for Biotechnology, University of Turku (Turku, Finland) (12), and maintained in growth medium comprising Dulbecco's modified Eagle's medium (DMEM; Lonza/BioWhittaker, Walkersville, MD, USA) supplemented with $10 \%$ fetal bovine serum (FBS; HyClone, GE Healthcare Life Sciences, Little Chalfont, UK), antibiotics $(100 \mathrm{U} / \mathrm{ml}$ penicillin and $100 \mu \mathrm{g} / \mathrm{ml}$ streptomycin; Lonza) and $200 \mathrm{mM}$ L-glutamine (Lonza) at $37^{\circ} \mathrm{C}$ in a humidified $5 \% \mathrm{CO}_{2}$ atmosphere. The composition of the differentiation medium was similar to the growth medium, with the exception of FBS, which was reduced from $10 \%$ to $1 \%$. The cells were passaged using trypsinization $(0.5 \%$ trypsin in $0.5 \mathrm{mM}$ EDTA; Gibco-BRL Life Technologies, Carlsbad, CA, USA) from the culture plate at $80 \%$ confluence.

Reverse transcription-quantitative polymerase chain reaction (RT-qPCR). To investigate the expression of histamine receptors in $\mathrm{C} 2 \mathrm{C} 12$ myogenesis, 50,000 cells/well were seeded in 12-well plates (CellStar; Greiner Bio-One, Frickenhausen, Germany). The cells were initially grown in growth medium for two days to reach $80 \%$ confluence. Next, the medium was exchanged with differentiation medium to induce myogenesis. Total RNA was isolated from the cells at days 0, 2, 4 and 6 using an RNeasy Mini kit (Qiagen, Düsseldorf, Germany) according to the manufacturer's instructions. Total RNA $(1 \mu \mathrm{g})$ was reverse transcribed using iScript cDNA Synthesis kit (Bio-Rad Laboratories, Inc., Hercules, CA, USA). RT-qPCR was performed with 100 ng first-strand cDNA using iQ SYBR ${ }^{\circledR}$ Green Supermix (Bio-Rad Laboratories, Inc.) in an iCycler iQ5 Multicolor Real-Time PCR Detection system (Bio-Rad Laboratories, Inc.). Primers for mouse desmin (Des), myogenin (Myog), myosin heavy chain IIa (Myh2), $\mathrm{H}_{1} \mathrm{R}, \mathrm{H}_{2} \mathrm{R}, \mathrm{H}_{3} \mathrm{R}, \mathrm{H}_{4} \mathrm{R}$ and porphobilinogen deaminase (PBGD) genes were designed using the National Center for Biotechnology Information Primer-Blast tool (Table I; http://www.ncbi.nlm.nih. gov/tools/primer-blast/; accessed: 01/03/2012). The mRNA copy numbers of the samples analyzed were determined in triplicate and normalized against the PBGD gene.

Immunofluorescence staining. The $\mathrm{C} 2 \mathrm{C} 12$ cells were seeded at $2 \times 10^{4}$ cells/well in 24 -well plates (CellStar) on coverslips and grown in growth medium for two days to reach $80 \%$ confluence, followed by culturing in differentiation 

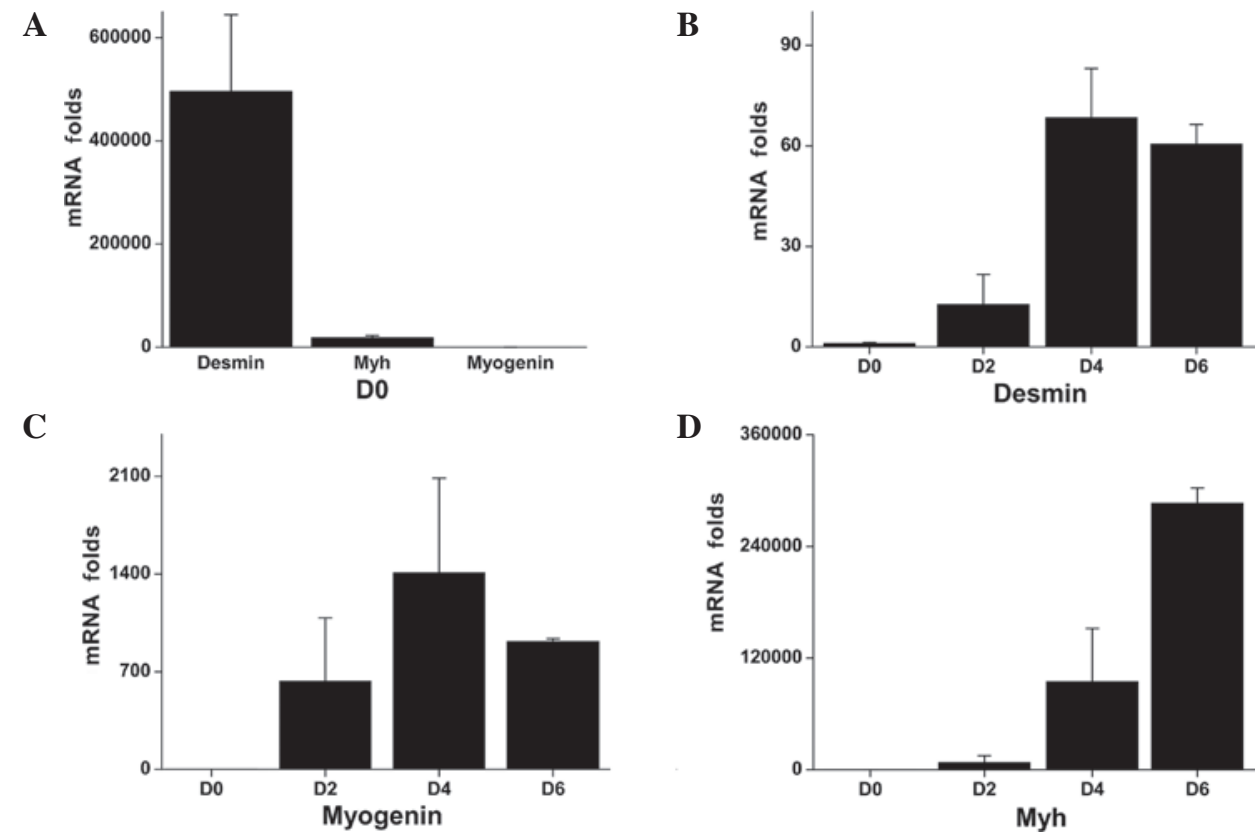

Figure 1. Myogenesis differentiation marker expression levels, determined by reverse transcription-quantitative polymerase chain reaction. (A) Relative expression levels of myogenic differentiation markers desmin (early marker), myogenin (intermediate marker) and Myh (late marker) in C2C12 cells at day 0 , and relative expression level variations in (B) desmin, (C) myogenin and (D) Myh during myogenesis at days 2, 4 and 6. The data are expressed as the mean \pm standard deviation. Myh, myosin heavy chain; mRNA, messenger RNA; D, day.

medium to induce myogenesis. Differentiated cells from days $0,2,4$ and 6 were fixed for $15-20 \mathrm{~min}$ in $4 \%$ paraformaldehyde (Sigma-Aldrich, St. Louis, MO, USA) with phosphate-buffered saline (PBS; 10mM phosphate buffer, $140 \mathrm{mM}$ saline; $\mathrm{pH}$ 7.4), washed three times in PBS (5 min each time) and in 0.5\% Triton X-100 (Thermo Fisher Scientific, Fair Lawn, NJ, USA)/PBS for 15 min to permeabilize the cells. Subsequently, the cells were cultured under the following conditions sequentially: i) 10\% normal donkey serum (Jackson Immunoresearch Laboratories, Inc., West Grove, PA, USA) for $1 \mathrm{~h}$; ii) $1 \mu \mathrm{g} / \mathrm{ml}$ polyclonal peptide affinity purified rabbit anti-human desmin (1:200), myogenin (1:400) or myosin heavy chain (Myh) immunoglobulin $\mathrm{G}(\mathrm{IgG} ; 1: 400)$ antibodies (obtained from Dr John E. Erikson, University of Turku, Turku, Finland) (12), or rabbit anti-human $\mathrm{H}_{3} \mathrm{R}$ polyclonal antibodies (1:1,000; LS-A476; MBL International, Woburn, MA, USA) at $4^{\circ} \mathrm{C}$ overnight and washed three times in PBS (5 min each time). Non-immune rabbit IgG $(1: 1,000 ; 1 \mu \mathrm{g} / \mathrm{ml}$; R\&D Systems, Minneapolis, MN, USA), was used at the same concentration as the primary antibodies as a negative staining control; iii) secondary antibody AlexaFluor ${ }^{\circledR} 488$-conjugated monoclonal donkey anti-rabbit IgG (1:400; Invitrogen Life Technologies, Carlsbad, CA, USA) in $0.1 \%$ bovine serum albumin (Sigma-Aldrich)-PBS for $1 \mathrm{~h}$ and washed three times in PBS (5 min each time); iv) DAPI dye (Sigma-Aldrich; 1:2,000 in distilled water) for $5 \mathrm{~min}$. The coverslips were washed twice in PBS and distilled water for $10 \mathrm{~min}$, prior to mounting with Vectashield medium (Vector Laboratories, Inc., Burlingame, CA, USA). Labeled slides were analyzed and photographed using a Leica DM $6000 \mathrm{~B} / \mathrm{M}$ fluorescence microscope, with a motorized Leica XY-stage connected to a Leica DFC 420 digital camera, and analyzed using the Leica Application Suite Advanced Fluorescence 2.5.0.6735 software (Leica Microsystems GmbH, Wetzlar, Germany).
Statistical analysis. SPSS software, version 17.0 (SPSS, Inc., Chicago, IL, USA) was used to perform statistical analyses in addition to Matlab (MathWorks, Inc., Natick, MA, USA), which was used to perform the Mann-Whitney U test. All values are presented as the mean \pm standard error of the mean. $\mathrm{P}<0.05$ was considered to indicate a statistically significant difference between values.

\section{Results}

Myogenesis of C2C12 cells. RT-qPCR was used to detect the mRNA expression levels of the early, intermediate and late myogenesis markers, desmin, myogenin and Myh2, respectively, during differentiation. On day 0 , desmin was expressed in myoblasts at significantly higher levels compared with the myogenin or Myh (Fig. 1A). The desmin expression levels increased during myogenesis, reaching $12-$, 68- and 60-fold over the baseline level (day 0), on days 2, 4 and 6, respectively (Fig. 1B). On day 0, the myogenin mRNA exxpression levels were low; however, the mRNA expression levels increased by 631-, 1,408- and 914-fold at days 2, 4 and 6, respectively (Fig. 1C). Desmin and myogenin expression levels peaked on day 4, whereas the expression of Myh, a late myogenesis marker, continued to increase over the entire study period, reaching 7,718-, 94,487- and 286,288-fold higher expression levels at days 2, 4 and 6, respectively, compared with the baseline level (Fig. 1D).

Indirect immunofluorescence staining of the myogenesis marker proteins revealed positive staining of the early marker, desmin, at day 0 (Fig. 2A); however, no staining was observed for the intermediate marker, myogenin (Fig. 2B), or the late marker, Myh (data not shown). On day 2, staining for myogenin was found to be positive (Fig. 3A), whereas staining for Myh remained negative (Fig. 3B). On 

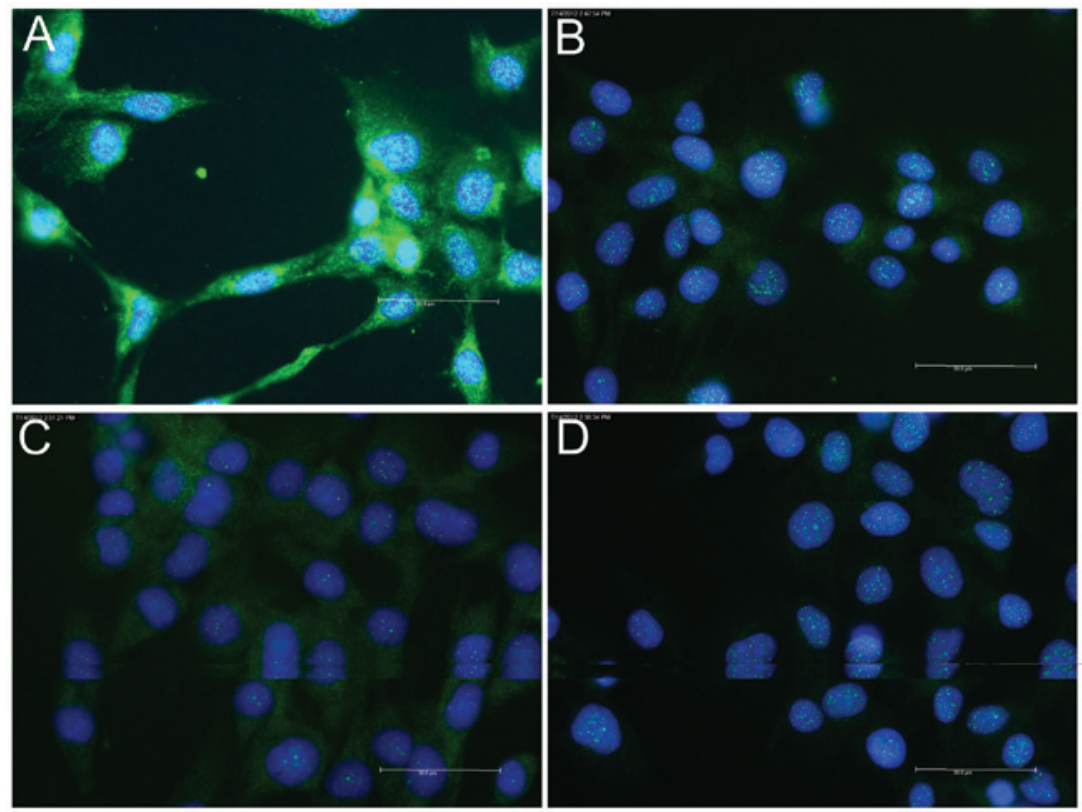

Figure 2. Immunofluorescent staining (green) of (A) desmin, (B) myogenin, (C) histamine receptor type 3 and (D) negative control at day 0 in undifferentiated $\mathrm{C} 2 \mathrm{C} 12$ cells. Staining of the late myogenic marker myogenin heavy chain was negative (not shown). DAPI was used for nuclear counterstaining (blue color). Scale bar, $50 \mu \mathrm{m}$.
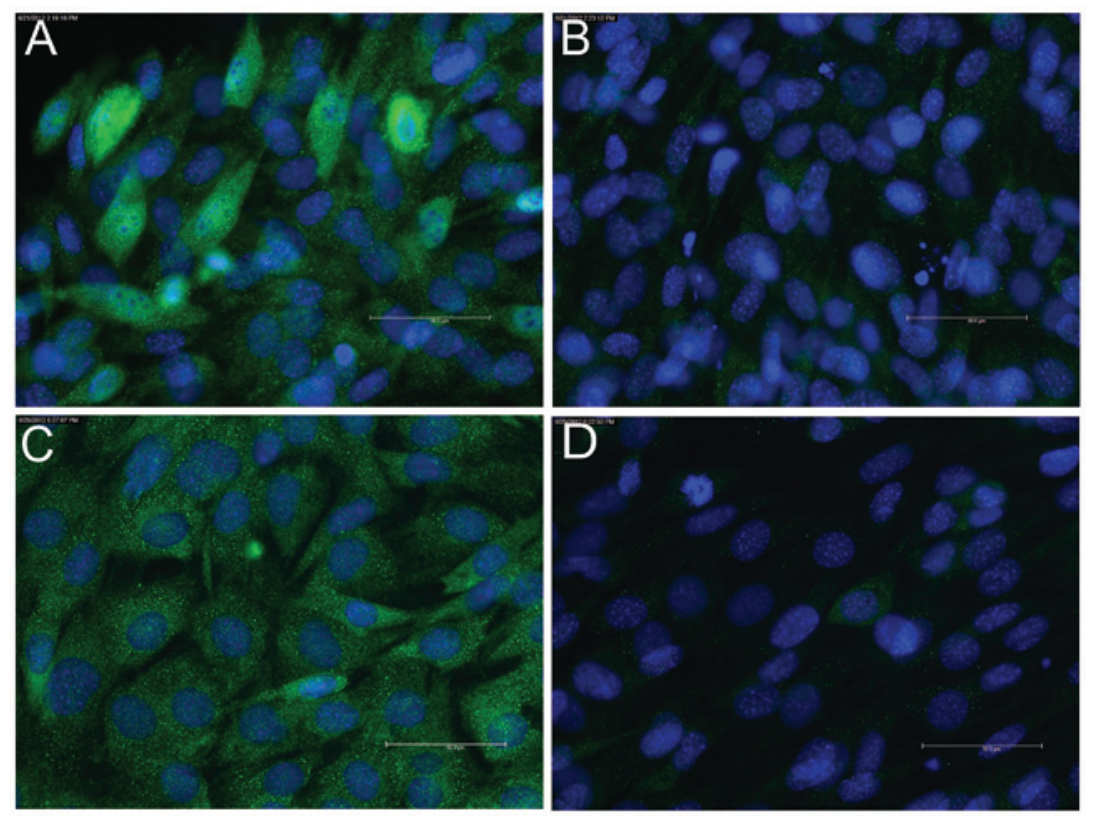

Figure 3. Immunofluorescent staining (green) of (A) myogenin, (B) myosin heavy chain, (C) histamine receptor type 3 and (D) negative control at day 2 in differentiated $\mathrm{C} 2 \mathrm{C} 12$ cells. DAPI was used for nuclear counterstaining (blue color). Scale bar, $50 \mu \mathrm{m}$.

days 4 (data not shown) and 6, positive staining for myogenin (Fig. 4A) and Myh (Fig. 4B) was detected.

Expression of histamine receptors. RT-qPCR was used to detect the mRNA expression levels of histamine receptors associated with the differentiation stages (Fig. 5). $\mathrm{H}_{1} \mathrm{R}$ mRNA was found to be highly expressed in $\mathrm{C} 2 \mathrm{C} 12$ myoblasts (day 0), whereas expression was decreased during the differentiation process (Fig. 5A and B). By day 6, the expression level decreased to $25 \%$ of the baseline level (day 0 ). $\mathrm{H}_{2} \mathrm{R}$ mRNA was also expressed in $\mathrm{C} 2 \mathrm{C} 12$ cells and the expression levels remained relatively constant throughout the differentiation process (Fig. 5A and C). The expression of $\mathrm{H}_{3} \mathrm{R}$ was found to be low in $\mathrm{C} 2 \mathrm{C} 12$ myoblasts; however, following differentiation, the expression levels increased by 28-, 103- and 198-fold over the baseline level on days 2, 4 and 6, respectively (Fig. 5A and D). $\mathrm{H}_{4} \mathrm{R}$ mRNA expression was not detected at any time-point.

Indirect immunofluorescence staining for $\mathrm{H}_{3} \mathrm{R}$ protein during the myogenesis of $\mathrm{C} 2 \mathrm{C} 12$ cells revealed almost negative staining at day 0 (Fig. 2C), weakly positive staining on day 2 (Fig 3C) and strongly positive staining on days 4 (data not shown) and 6 (Fig. 4C). 

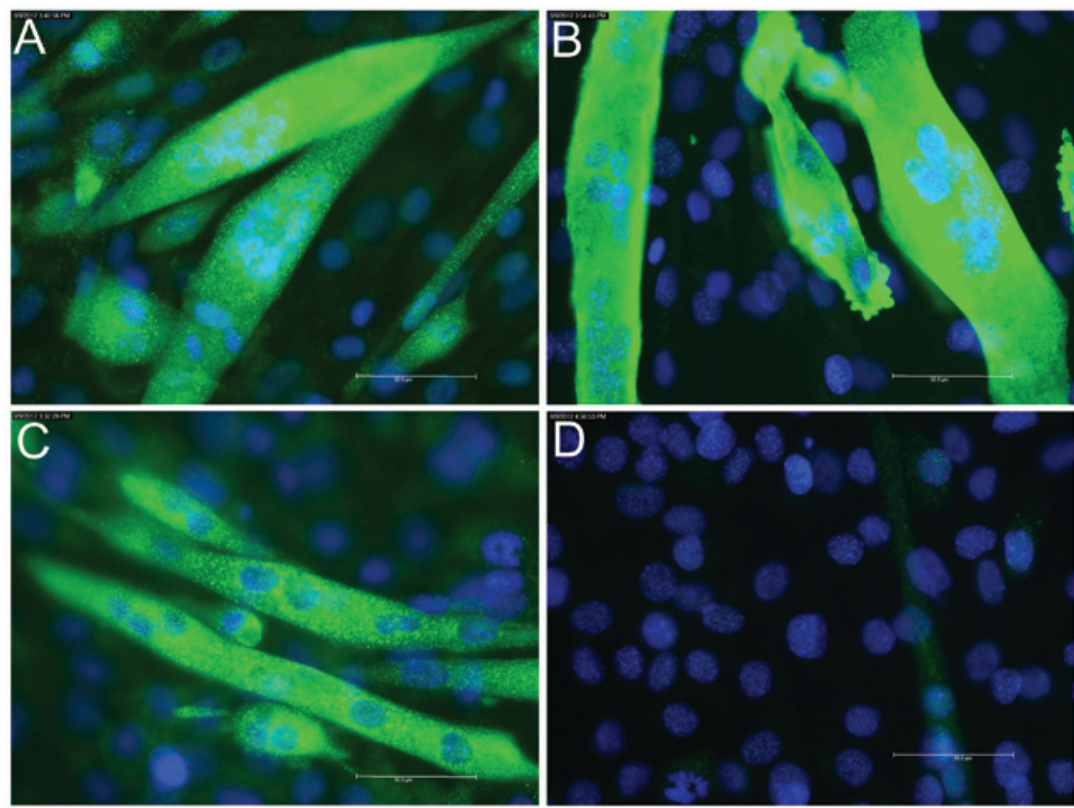

Figure 4. Immunofluorescent staining (green) of (A) myogenin, (B) myosin heavy chain, (C) histamine receptor type 3 and (D) negative control at day 6 in differentiated $\mathrm{C} 2 \mathrm{C} 12$ cells. DAPI was used as a nuclear counterstain (blue color). Scale bar, $50 \mu \mathrm{m}$.

A

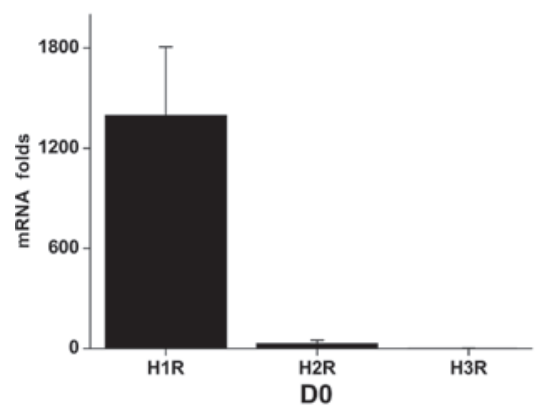

C

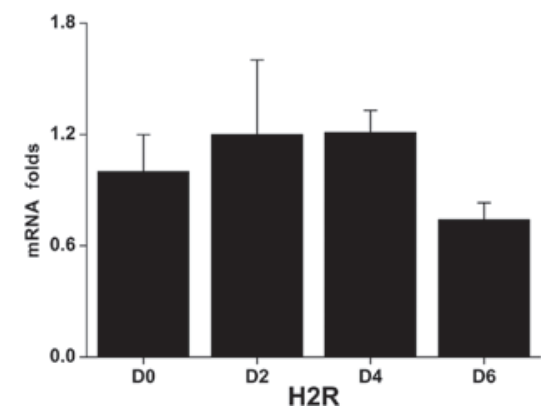

B

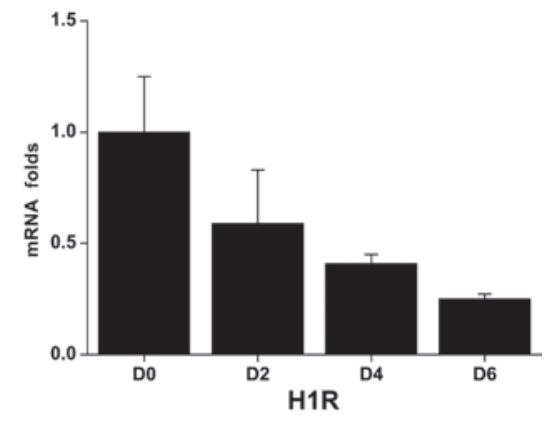

D

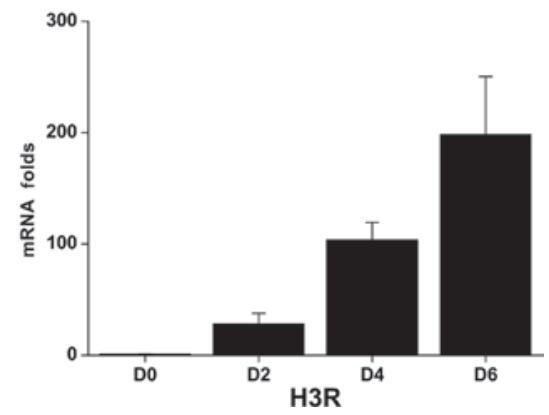

Figure 5. Histamine receptor subtype expression levels, determined by reverse transcription-quantitative polymerase chain reaction. (A) Relative expression levels of $\mathrm{H}_{1} \mathrm{R}, \mathrm{H}_{2} \mathrm{R}$ and $\mathrm{H}_{3} \mathrm{R}$ in $\mathrm{C} 2 \mathrm{C} 12$ cells at day 0 , and relative expression level variations of (B) $\mathrm{H}_{1} \mathrm{R},(\mathrm{C}) \mathrm{H}_{2} \mathrm{R}$ and (D) $\mathrm{H}_{3} \mathrm{R}$ during myogenesis (days 0-6). The data are expressed as the mean \pm standard deviation. mRNA, messenger RNA; $H_{n} R$, histamine receptor type $n$ (where $n=1,2$ or 3 ).

\section{Discussion}

To the best of our knowledge, the present study demonstrated for the first time that striated muscle cells expressed $\mathrm{H}_{1} \mathrm{R}$, $\mathrm{H}_{2} \mathrm{R}$ and $\mathrm{H}_{3} \mathrm{R}$-coding mRNA and corresponding receptor proteins, but lacked receptor, $\mathrm{H}_{4} \mathrm{R}$. The lack of $\mathrm{H}_{4} \mathrm{R}$ in striated muscle cells may be due to the fact that $\mathrm{H}_{4} \mathrm{R}(+)$ cells have been previously been identified in the bone marrow, thymus and spleen, as well as at the cellular level in bone marrow-derived cells, including mast cells, basophils, eosinophils, neutrophils, dendritic cells and lymphocytes (13).

Investigation of the early, intermediate and late phases of myogenesis was performed using desmin, myogenin and Myh as markers, respectively. The results indicated that histamine receptors were dynamically regulated during differentiation, suggesting that they may have distinct regulatory functions. $\mathrm{H}_{1} \mathrm{R}$ presented the highest expression in myoblasts on day 0 , compared with the other receptors; however, the expression levels of $\mathrm{H}_{1} \mathrm{R}$ were subsequently decreased during myogenesis. 
$\mathrm{H}_{2} \mathrm{R}$ expression was found to be low on day 0 and remained relatively constant throughout all the phases of myogenesis. By contrast, $\mathrm{H}_{3} \mathrm{R}$ showed the lowest expression in myoblasts on day 0 ; however, the $\mathrm{H}_{3} \mathrm{R}$ expression levels were subsequently increased, and continued to increase throughout myogenesis.

The low affinity of $\mathrm{H}_{1} \mathrm{Rs}$ for histamine requires burst release from professional histamine-synthesizing cells in order to induce target cell effects. Notably, in cardiomyocyte precursor cells, $\mathrm{H}_{1} \mathrm{Rs}$ are abundant and regulate $\mathrm{Ca}^{2+}$ oscillation and frequency. In such progenitor cells, this process is coupled with the entry of cells into the cell cycle and bromodeoxyuridine incorporation (5). The results of the present study, which revealed high levels of $\mathrm{H}_{1} \mathrm{R}$ expression during early myogenesis, along with the aforementioned previous observations, suggested that high histamine levels may stimulate myoblast proliferation during the early phases of differentiation. This hypothesis is further supported by the observations of a previous study, which demonstrated that mast cell precursors migrated from bone marrow to skeletal muscle tissue in 17 to 20-day-old rat fetuses, indicating interactions between the professional histamine-producing mast cells and skeletal muscle cells in proliferation or differentiation (14).

In the present study, $\mathrm{H}_{2} \mathrm{R}$ expression remained constant throughout all the phases of myogenesis, and thus, may be involved in the maintenance of relaxation following burst release of histamine (since $\mathrm{H}_{2} \mathrm{R}$ stimulation requires high histamine concentrations), with a curare-like effect (which is a competitive antagonist of the nicotinic acetylcholine receptor) (15). By contrast, $\mathrm{H}_{2} \mathrm{R}$ antagonists have been demonstrated to possess an anti-cholinesterase activity (16).

Due to the high affinity of $\mathrm{H}_{3} \mathrm{R}$ for histamine, the non-professional histamine-producing cells are able to stimulate $\mathrm{H}_{3} \mathrm{R}$-expressing cells. The levels of histamine released by the non-professional histamine-producing cells are not sufficient to activate the conventional, low-affinity receptors (2). Furthermore, in contrast to the conventional $\mathrm{H}_{1} \mathrm{R}$ and $\mathrm{H}_{2} \mathrm{R}, \mathrm{H}_{3} \mathrm{R}$ has a relatively high constitutive activity level, which is $\sim 25 \%$ active in the absence of $\mathrm{H}_{3} \mathrm{R}$-ligands $(17,18)$. According to the two-state model of receptor activation, G-protein coupled receptors exist in equilibrium between an active and inactive receptor state. Upon ligand binding, the G-protein becomes activated $\left(\mathrm{R}^{*}\right)$ and begins to 'couple' and transduce the extracellular stimulus into an intracellular signal, while ligand-free G-protein coupled receptors exist in a passive, uncoupled conformation. However, $\mathrm{H}_{3} \mathrm{R}$ spontaneously acquires the $\mathrm{R}^{*}$ state, which promotes G-protein-mediated signaling in the absence of an agonist. Therefore, $\mathrm{H}_{3} \mathrm{R}$ is hypothesized to have significant constitutive functions in mature myocytes and myotubes, which are independent of burst release (cellular emergencies) and driven by the low histamine concentrations generated by non-professional histamine-producing cells and by their constitutive activity $(17,18)$.

High histamine concentrations are known to mediate the pathological contraction of smooth muscles cells in the bronchiolar walls, including during acute attacks of asthma and anaphylactic reactions mediated by $\mathrm{H}_{1} \mathrm{R} . \mathrm{H}_{1} \mathrm{R}$ is coupled to $\mathrm{G} \alpha_{\mathrm{q} / 11}$ protein, which cleaves phosphatidylinositol 4,5-bisphosphate to diacylglycerol and inositol 1,4,5-trisphosphate, via the activation of phospholipase $\mathrm{C}$. This results in $\mathrm{Ca}^{2+}$ influx and initiates smooth muscle contraction (3). Notably, low histamine concentrations act as potent relaxant agents for pre-contracted smooth muscle cells via $\mathrm{H}_{3} \mathrm{Rs}$ (3). In the present study, the time course of $\mathrm{H}_{3} \mathrm{R}$ expression during myogenesis indicated that $\mathrm{H}_{3} \mathrm{R}$ may have long-term, constitutive effects on mature skeletal muscles cells, rather than being activated under exceptional circumstances that results in burst release of the histamine stores from mast cells and basophils. Based on the findings of Cardell and Edvinsson (3) and the long-term low histamine level-induced and constitutive $\mathrm{H}_{3} \mathrm{R}$ function, $\mathrm{H}_{3} \mathrm{R}$ was hypothesized to maintain the relaxed state of mature skeletal muscle cells.

In conclusion, further studies are required in order to determine the functions and potential signalling pathways by which the expression of the three histamine receptor subtypes, examined in the present study, are regulated during myogenesis in skeletal muscle cells. Future research may elucidate novel information regarding the etiology and potential treatment of skeletal muscle diseases.

\section{Acknowledgements}

The work of Drs Chen, Stegaev, Sillat, Kouri and Konttinen was supported by the Finska Läkaresällskapet, Orion-Farmos Foundation, Sigrid Jusélius Foundation, ORTON Invalid Foundation, HUS evo-grants, Academy of Finland, Center for International Mobility CIMO and the Danish Council for Strategic Research and Regenerative Medicine RNP of the European Science Foundation. The work of Dr Stark was supported by the Hesse LOEWE programs OSF, NeFF, AFA and the TRIP. The work of Dr Chazot was supported by the Royal College of Anaesthesia, BBSRC (UK). This study was supported by the EU COST Action BM0806.

The authors would like to thank Professor John E. Eriksson at the Turku Center for Biotechnology, Department of Biosciences, University of Turku and Åbo Akademi University (Turku, Finland) for providing the cells and antibodies.

\section{References}

1. Ichikawa A, Sugimoto Y and Tanaka S: Molecular biology of histidine decarboxylase and prostaglandin receptors. Proc Jpn Acad Ser B Phys Biol Sci 86: 848-866, 2010.

2. Walter M and Stark H: Histamine receptor subtypes: a century of rational drug design. Front Biosci (Schol Ed) 4: 461-488, 2012.

3. Cardell LO and Edvinsson L: Characterization of the histamine receptors in the guinea-pig lung: evidence for relaxant histamine H3 receptors in the trachea. Br J Pharmacol 111: 445-454, 1994.

4. Neuhaus J, Weimann A, Stolzenburg JU, et al: Histamine receptors in human detrusor smooth muscle cells: physiological properties and immunohistochemical representation of subtypes. World J Urol 24: 202-209, 2006.

5. Ferreira-Martins J, Rondon-Clavo C, Tugal D, et al: Spontaneous calcium oscillations regulate human cardiac progenitor cell growth. Circ Res 105: 764-774, 2009.

6. Wellner-Kienitz MC, Bender K, Meyer T and Pott L: Coupling to $\mathrm{G}_{\mathrm{s}}$ and $\mathrm{G}_{\mathrm{q} / 11}$ of histamine $\mathrm{H}_{2}$ receptors heterologously expressed in adult rat atrial myocytes. Biochim Biophys Acta 1642: 67-77, 2003.

7. Fukui H, Fujimoto K, Mizuguchi H, et al: Molecular cloning of the human histamine $\mathrm{H}_{1}$ receptor gene. Biochem Biophys Res Commun 201: 894-901, 1994

8. Emami Riedmaier A, Nies AT, Schaeffeler E, et al: Organic anion transporters and their implications in pharmacotherapy. Pharmacol Rev 64: 421-449, 2012.

9. Szeberényi J B, Pállinger E, Zsinkó M, et al: Inhibition of effects of endogenously synthesized histamine disturbs in vitro human dendritic cell differentiation. Immunol Lett 76: 175-182, 2001. 
10. Kubo $\mathrm{Y}$ and Nakano K: Regulation of histamine synthesis in mouse $\mathrm{CD}^{+}$and $\mathrm{CD}^{+} \mathrm{T}$ lymphocytes. Inflamm Res 48: 149-153, 1999.

11. Radvány Z, Darvas Z, Kerekes K, et al: H1 histamine receptor antagonist inhibits constitutive growth of Jurkat $T$ cells and antigen-specific proliferation of ovalbumin-specific murine T cells. Semin Cancer Biol 10: 41-45, 2000.

12. Pallari HM, Lindqvist J, Torvaldson E, et al: Nestin as a regulator of Cdk5 in differentiating myoblasts. Mol Biol Cell 22: 1539-1549, 2011.

13. ZampeliEandTiligadaE:Theroleofhistamine $\mathrm{H}_{4}$ receptorinimmune and inflammatory disorders Br J Pharmacol 157: 24-33, 2009.

14. Cheng CX, Li YN, Ohno H, et al: Mast cells appearing in long-term skeletal muscle cell cultures of rat. Anat Rec (Hoboken) 290: 1424-1430, 2007.
15. Ohta Y, Ariyoshi M and Koketsu K: Histamine as an endogenous antagonist of nicotinic ACh-receptor. Brain Res 306: 370-373, 1984.

16. Cheah LS, Lee HS and Gwee MC: Anticholinesterase activity of and possible ion-channel block by cimetidine, ranitidine and oxmetidine in the toad isolated rectus abdominis muscle. Clin Exp Pharmacol Physiol 12: 353-357, 1985.

17. Rouleau A, Ligneau X, Tardivel-Lacombe J, et al: Histamine $\mathrm{H}_{3}$ receptor-mediated $\left[{ }^{35} \mathrm{~S}\right] \mathrm{GTP}$ gamma (S) binding: evidence for constitutive activity of the recombinant and native rat and human $\mathrm{H}_{3}$ receptors. Br J Pharmacol 135: 383-392, 2002.

18. Arrang JM, Morisset S and Gbahou F: Constitutive activity of the histamine H3 receptor. Trends Pharmacol Sci 28: 350-357, 2007. 